\title{
16. CARBON ISOTOPE DATA FROM LEG 74 SEDIMENTS ${ }^{1}$
}

\author{
N. J. Shackleton and M. A. Hall, Godwin Laboratory, Free School Lane, Cambridge CB2 3RS, England
}

\begin{abstract}
Carbon and oxygen isotope measurements were made in bulk sediments from the five sites drilled on Leg 74 , covering much of the Cenozoic.

These stable carbon isotope analyses document a lightening across the Cretaceous/Tertiary boundary (already documented by other workers), with a minimum about $0.2 \mathrm{Ma}$ after the boundary; a trend to very heavy values in the late Paleocene; a lightening near the Paleocene/Eocene boundary to a second minimum early in the early Eocene; more positive values in the remainder of the Eocene with a minor peak immediately below the Eocene/Oligocene boundary, at which there is a lightening trend; a moderately positive peak in the middle Miocene, and a lightening toward the present, where the isotopically lightest values in the Cenozoic are to be found. The carbon isotope variations observed are largely a function of changes in the ${ }^{13} \mathrm{C}$ content of oceanic dissolved inorganic carbon that resulted from alterations in the global carbon budget. Slight differences among sediments of the same age at different sites probably result from diagenetic changes, but do not obscure the major pattern, which has considerable potential value for stratigraphic correlation.
\end{abstract}

\section{INTRODUCTION}

The explanation for changes in carbon isotopic composition in foraminifers has attracted some interest in recent years. Shackleton (1977) proposed a model which attempted to explain Pleistocene carbon isotope variations in terms of the terrestrial biomass budget. More recently a modification of this model has been found necessary because of marked differences in the signal observed in different oceans: presently unpublished work has shown that the Atlantic experienced a significantly larger signal than the Pacific because the production rate of North Atlantic Deep Water (NADW) varied. In the Cenozoic, attention has focused on a late Miocene change observed in most parts of the ocean (Keigwin, 1979; Vincent et al., 1980; Keigwin and Shackleton, 1980; Haq et al., 1980). Bender and Keigwin (1979) discussed the cause of this, setting up testable models dependent on changes in oceanic circulation, nutrient input factors, and variations in the ${ }^{13} \mathrm{C}$ content of incoming carbon. In the Mesozoic, Scholle and Arthur (1980) analyzed bulk rock from widely distributed Cretaceous sections, showed that the variations are synchronously recorded, and argued that they reflect carbon budgetary changes. Letolle and Renard (1980) and Renard et al. (in press) gathered analogous data for parts of the Cenozoic. Boersma et al. (1979) showed that bulk sediment, as well as picked foraminifers, record a lightening across the Cretaceous/Tertiary boundary which probably reflects the dramatic drop in marine productivity at that time. Vincent et al. (1980) also drew attention to several other factors that could conspire to cause a carbon isotope change of the nature observed in the late Miocene.

The purpose of this paper is to present a record of carbon isotope variations in bulk sediment from the

\footnotetext{
${ }^{1}$ Moore, T. C., Jr., and Rabinowitz, P. D., et al., Init. Repts. DSDP, 74: Washington (U.S. Govt. Printing Office).
}

Late Cretaceous to the Recent, and to discuss the carbon isotope record in conjunction with that obtained from picked foraminifers. Data from several sites are used. Some comparison between contemporary samples deposited at different depths is possible in view of the range of sites drilled; these lend credence to the compilation as a guide to global changes. It must be emphasized that the purpose of analyzing bulk sediment is to obtain the ${ }^{13} \mathrm{C}$ content of stored carbonate carbon through geological time. It is well known that the ${ }^{13} \mathrm{C}$ content of organic matter averages in the range -20 to $-25 \%$; the partitioning of carbon between organic and inorganic sinks may, therefore, be estimated by the ${ }^{13} \mathrm{C}$ content of the inorganic part, that is, the deep sea carbonate sediment.

\section{METHODS}

Stable isotope measurements were made using standard methods (Shackleton and Opdyke, 1973). The only additional comment that should be made is that the methods used were developed primarily for the purpose of analyzing very small samples of carbonate (down to $<0.1 \mathrm{mg}$ ); the routine adopted is not so suitable for samples larger than a few mg. Because deep sea sediment which is composed of coccoliths, foraminifers, and other material is inherently inhomogeneous, our reproducibility is not as good as it would be if larger samples were analyzed. Doubtful analyses are always repeated where possible, and values that are discrepant both with repeated analyses and with values from nearby samples are not discussed further (they are, however, listed).

\section{RESULTS}

All analytical data are given in the chapter Appendix. Figure 1 shows a compilation of all the data from the late Maestrichtian to Eocene on a single timescale. Figure 2 shows data for the whole of the Cenozoic as a composite. To optimize correlation between sites, ages are estimated using every nannofossil zone boundary, placed at the midpoint of the limits determined, and assigned an age according to the timescale in Shackleton et al. (this volume, accumulation chapter). 


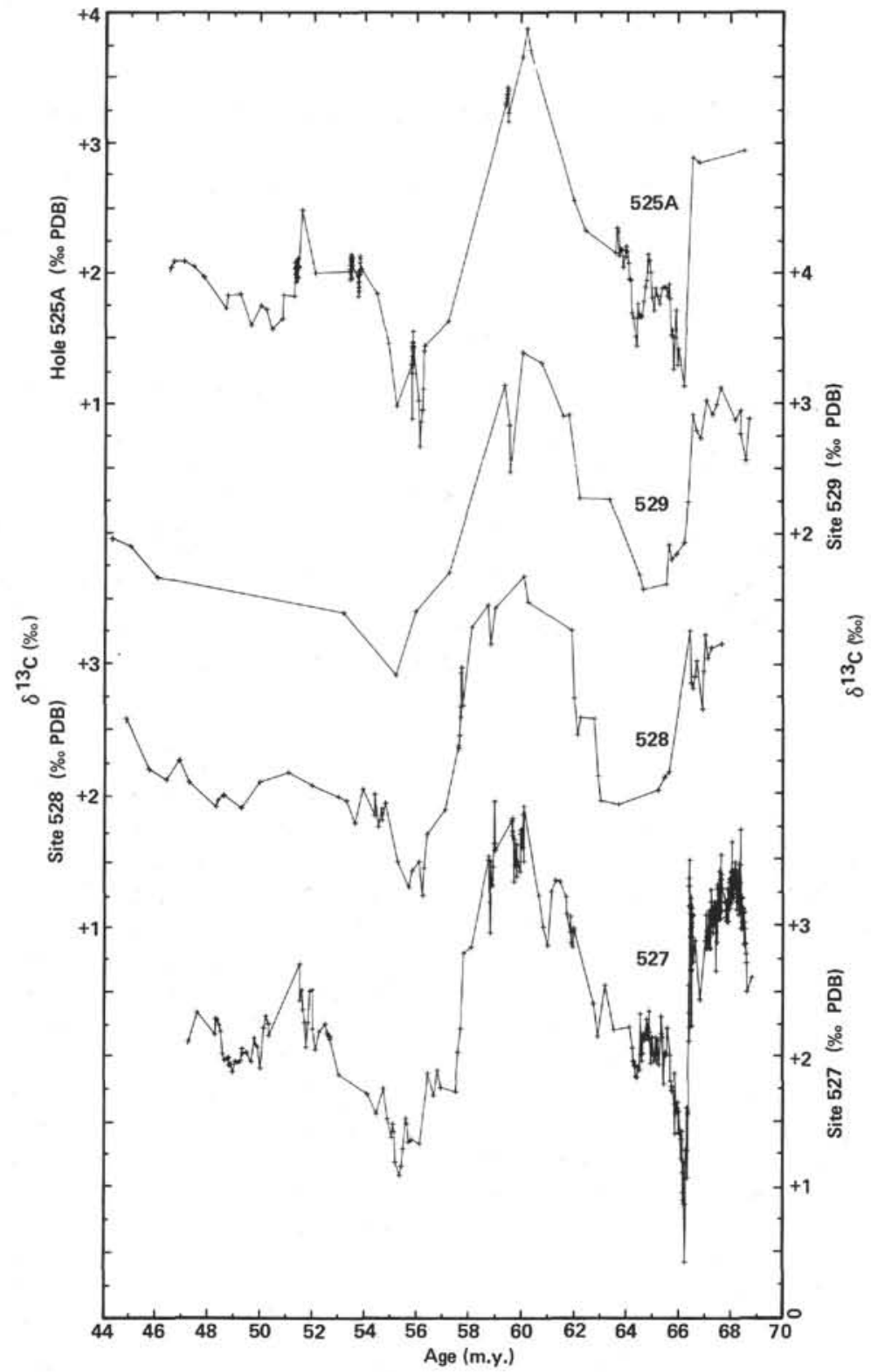

Figure 1. Carbon isotopic composition of bulk sediments from Sites 525, 527, 528 , and 529, plotted on a common timescale, for the Eocene to Maestrichtian. Data from the chapter Appendix.

It is rather clear that, at least at the degree of resolution obtained until now, there is an excellent consistency between sites. Indeed, a superficial examination of Figure 1 suggests that in the Paleocene, where the carbon isotope signal is very large, the cores could be correlated on the basis of the carbon isotope records, with an accuracy similar to that attainable by traditional biostratigraphical methods.

\section{Between-Site Variations}

Because the residence time of carbon in the ocean is of the order of 300,000 yr. (Broecker, 1974), sampling for the purpose of determining changes in the global carbon budget should be close enough to provide several samples per 300,000 yr. Our sampling in the lower Paleocene intervals of Sites 525 and 527 fulfilled this requirement. It will be seen that the pattern of variation is similar at the two sites but that there is a slight offset, amounting to approximately $0.3 \%$. The sediment from Site 525 is isotopically heavier. Whether this is a diagenetic effect on one or other of the carbonate components or whether it merely reflects seafloor dissolution of one component has yet to be determined. It is in general the case that surfacedwelling foraminifers are dissolved more readily than the deeper-dwelling species-a fact which should imply that dissolution removes the most isotopically heavy part of the carbonate (Berger, 1971) - but there is a further complexity. Smaller foraminifers are also more soluble than larger, and it is generally the case that juvenile tests are isotopically lighter (Berger et al., 1978). Thus dissolution may leave a sediment isotopically heavier in some circumstances. In general diagenesis is more likely to leave 


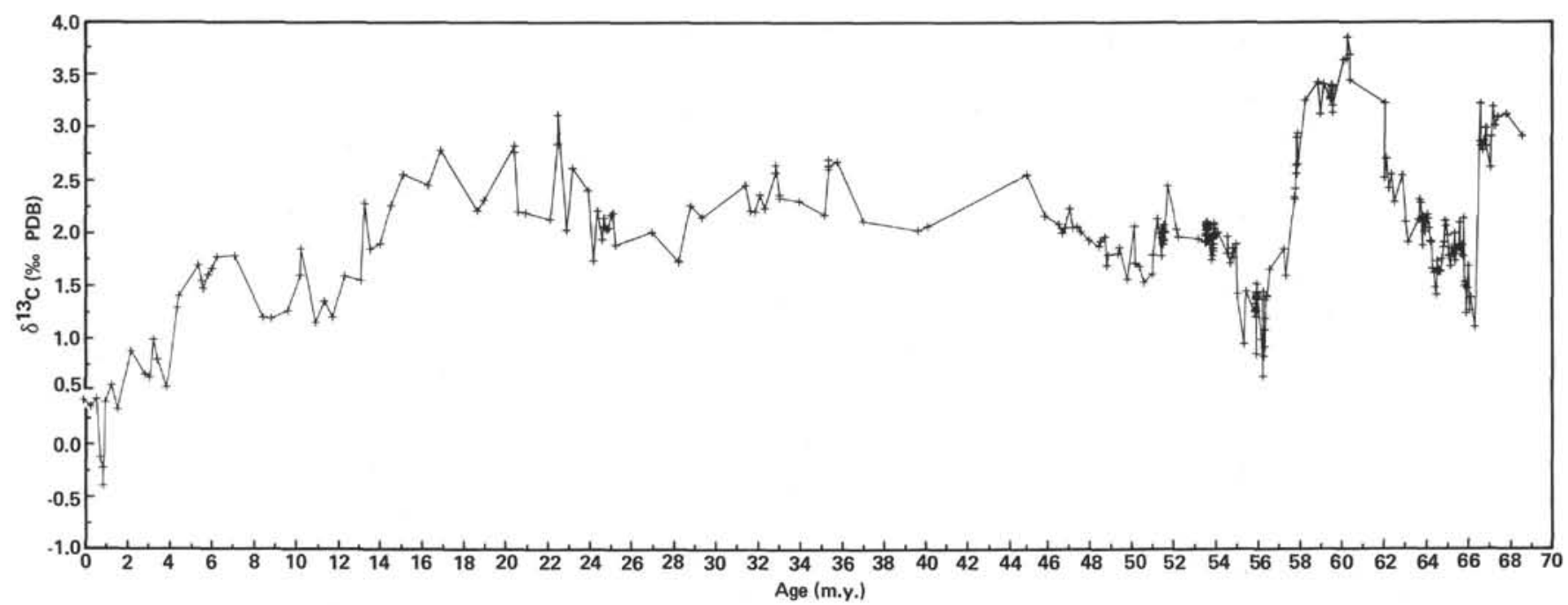

Figure 2. Carbon isotopic composition of bulk sediment from Site 525, with data from Site 528 between 25 and 45 Ma. Data from the chapter Appendix.

the carbonate isotopically lighter for carbon, since the carbon in the organic matter is isotopically light. However, for the lower Paleocene sediment in these two sites, visual examination suggests that Site 527 sediment has experienced only slight dissolution, whereas the shallower Site 525 shows evidence of considerable reprecipitation of calcite, probably as a result of deeper burial.

\section{DISCUSSION}

The scale of the carbon isotope variation, particularly in the Paleogene, is potentially very valuable for stratigraphic correlation. It is clear that the amount of change within some zones, for example, NP5 or NP9 (respectively 62 to $61.3 \mathrm{Ma}$, and 58.8 to $57.8 \mathrm{Ma}$, on the timescale used here), is sufficiently large to provide an easily accessible extra degree of stratigraphic correlation, at least between the Leg 74 sites. Indeed, this became evident when the data first became available, because plotting the ${ }^{13} \mathrm{C}$ data on the basis of nannofossil zone boundaries only gave rise to major between-site discrepancies in Zone NP9. Dr. Jan Backman generously determined several additional datums in this interval; their value is demonstrated by the better between-site agreement of the ${ }^{13} \mathrm{C}$ records plotted against estimated age. It seems quite likely that this stratigraphic correlation would be widely useful. For example, the wholerock ${ }^{13} \mathrm{C}$ record in the Paleogene sequences at Gubbio in the Umbrian region (Létolle and Renard, 1980) can be readily correlated with open ocean records. This is of value, because preservation in the Gubbio section is not ideal for detailed micropalaeontological work. Foraminifers must be identified in thin section (Premoli Silva, 1977), whereas the magnetic data from DSDP sites are very frequently marred by drilling disturbance.

\section{Cretaceous/Tertiary Boundary}

It is now well known that a carbon isotope change is observed across the Cretaceous/Tertiary boundary (Thierstein and Berger, 1978; Boersma et al., 1979; Boersma and Shackleton, 1982; Thierstein, 1981, Hsü et al., 1982;). Generally, isotopically lighter values are obtained just above the boundary.

Hsü et al. (1982) analyzed bulk sediment from DSDP Site 524, recovered at the end of Leg 73. They found isotopically very light $(-5 \%) \delta^{13} \mathrm{C}$ values immediately above the boundary and attributed these to an influx of isotopically light terrestrial biomass, which isotopically lightened the surface layer for a short time until it was well mixed into the deep ocean (as will happen to the isotopically light fossil fuel $\mathrm{CO}_{2}$ in the next century). They observed a second peak of extremely isotopically light values near the top of the reversed interval containing the boundary. We did not observe such extreme values; we believe that the extreme values that they obtained, and that were associated with very low carbonate contents, may have been an artifact of this low carbonate content, rather than reflecting the true isotopic composition of the carbonate being deposited at that time.

Site 527 provides our best data from this time interval. All the plugs used for palaeomagnetic determinations were analyzed, as well as some additional samples. The data are shown on an expanded timescale in Figure 3. The Cretaceous/Tertiary boundary itself is marked by a lightening by about $1.0 \%$. Within the lower Danian there is a further lightening by about $2 \%$, the minimum being reached at about $0.2 \mathrm{~m} . \mathrm{y}$. after the boundary. This is followed by a reversal in trend which culminates in the most positive values for the whole Tertiary, achieved in the upper Paleocene at about $58 \mathrm{Ma}$.

It is always difficult to ascertain precisely what occurred chemically at this boundary because of the loss of so many of the species carrying the geochemical information. Fortunately for our study, the benthic faunas were more or less unaffected; a mixture of Nuttalides and Gavelinella spp. analyzed on either side of the boundary yielded statistically indistinguishable ${ }^{13} \mathrm{C}$ values. In order to estimate the true change in surface water ${ }^{13} \mathrm{C}$ content, we analyzed an assemblage of mixed, very small foraminifers (size range 63-75 $\mu \mathrm{m}$ ) from sam- 


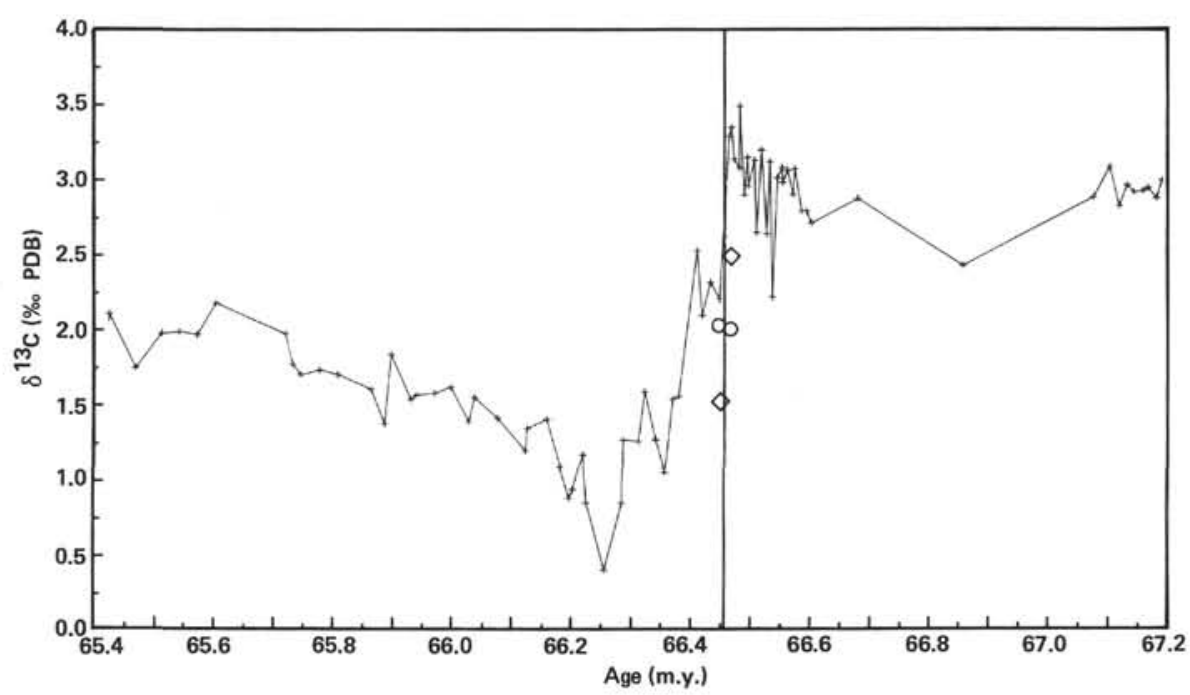

Figure 3. Carbon isotopic composition of bulk sediment from Site 527 near the Cretaceous/Tertiary boundary. A line is drawn between the last Cretaceous sample analyzed and the lowest Danian sample; their separation is $20 \mathrm{~cm}$. Also shown are analyses of benthic foraminifers (circles) and of small $(63-75 \mu \mathrm{m})$ planktonic foraminifers (squares) in the two samples adjacent to the boundary.

ples about $10 \mathrm{~cm}$ above and below the boundary. The Maestrichtian sample yielded a ${ }^{13} \mathrm{C}$ value similar to that given for $\boldsymbol{A}$. mayeroensis, a little lighter than the most positive species analyzed. The Danian sample was picked over to remove any Cretaceous specimens. Although this procedure cannot be proven to give a reliable estimate of the true change in oceanic ${ }^{13} \mathrm{C}$ content, it provides a valuable check on the bulk sediment data (which are, of course, dominated by coccoliths). It is impossible to select an uncontaminated basal Danian coccolith fraction, since the fine fraction (like the Cretaceous material) contains much micritic matter. The fact that the very small foraminiferal fraction yields a similar signal leads us to conclude that this was the true record. It is entirely explicable in terms of a sudden and drastic drop in marine productivity, which would have had the effect of diminishing the isotopic contrast between surface and deep water.

If surface productivity were suddenly to become negligible, surface and deep water would become isotopically indistinguishable. In essence, we believe that this is what actually occurred. Excellent magnetic data (Chave, this volume) shows that accumulation rates (which, in these sites, are controlled by biogenic productivity) dropped by about a factor of three (Shackleton et al. this volume). We have not attempted to address the question of what occurred at this boundary on a timescale of less than a few thousand years, but we consider that the contrast between the latest Cretaceous ocean and that of the early Cenozoic lay in the fraction of the available carbon that was photosynthesized in the surface layers of the ocean, and in the rate of accumulation of organic matter. The drop in the amount of carbon photosynthesized led immediately to a collapse of the surface-to-deep ${ }^{13} \mathrm{C}$ gradient. The drop in global organic carbon accumulation created an imbalance between the mean isotopic composition of incoming carbon and sedimented carbon, that over a longer time period (con- trolled by the residence time of carbon in the ocean) was compensated for by a change in the ${ }^{13} \mathrm{C}$ content of the ocean. It is this change that is reflected by the ${ }^{13} \mathrm{C}$ content of benthic foraminifers.

\section{Paleocene}

A marked excursion toward positive ${ }^{13} \mathrm{C}$ values in benthic and planktonic foraminifers during the early Paleogene has been noted previously (Douglas and Savin, 1971; Shackleton and Kennett, 1975). Figure 1 reveals that this is equally clearly shown by the bulk sediment analyses, which thus confirm that the phenomenon was budgetary. Comparison of the ${ }^{13} \mathrm{C}$ values obtained for calibrated benthic foraminifers and for surface-dwelling morozovellids (Shackleton et al., this volume) suggests that at the time when ${ }^{13} \mathrm{C}$ values were most positive, the surface-to-deep water gradient was at its maximum. This suggests (but does not prove) that the ${ }^{13} \mathrm{C}$ maximum of the late Paleocene was enhanced by photosynthetic removal of carbon from the ocean system.

The Paleocene/Eocene boundary interval is marked by a collapse in the ${ }^{13} \mathrm{C}$ values that was greater in magnitude than that at the end of the Cretaceous, although it was more gradual. In this interval the rate of change of carbon isotopic composition provides potentially very accurate stratigraphic correlation, and it will be very interesting to see if this can be exploited.

\section{Eocene and Oligocene}

The ${ }^{13} \mathrm{C}$ values became somewhat more positive after the isotopically light extreme at the base of the Eocene, but the sediment recovery at Leg 74 sites was not suitable for establishing a good late Eocene record. The Eocene/Oligocene boundary is marked by characteristic variations which warrant more detailed study at other sites. 
We have not attempted to obtain a detailed Oligocene record, since Site 529, the only site where a good thickness of Oligocene sediments was obtained, contains many slumped intervals.

\section{Neogene}

The Miocene shows a ${ }^{13} \mathrm{C}$ maximum, although it is less dramatic than that in the late Paleocene. Our data are not sufficient to establish whether it was accompanied by a maximal surface-to-deep carbon isotope gradient as in the Paleocene. In any case, none of the Leg 74 sites had sufficiently good recovery of the middle Miocene to warrant a detailed study of this interval. The collapse toward the Present is even more dramatic, although even more gradual, than those documented in the Paleogene. Presently, carbonate in the deep sea is forming with an anomalously light ${ }^{13} \mathrm{C}$ composition by comparison with the rest of the Cenozoic. It is surprising that there has been no systematic survey of the carbon isotopic composition of Recent marine sediments.

\section{CONCLUSIONS}

The carbon isotopic composition of bulk sediment from the Leg 74 sites shows this to be an important aspect of the stratigraphic record of the deep sea. It is valuable as a guide to accurate intercore correlation and for the information it provides on the global partitioning of carbon between the two major sinks that may be generalized as "limestone" and "organic carbon."

\section{ACKNOWLEDGMENTS}

This study would not have been possible without the noble cooperation of Captain Clark and the crew of the Glomar Challenger. We are especially conscious of the work put in by our scientific colleagues, and by Bill Mills and his associates, in taking the large number of samples that the study entailed. We gratefully acknowledge the financial support of the National Environment Research Council both toward the Deep Sea Drilling Project and the isotope laboratory in Cambridge.

\section{REFERENCES}

Bender, M. L., and Keigwin, L. D., Jr., 1979. Speculations about the upper Miocene change in abyssal Pacific dissolved carbonates $\delta^{13}$ C. Earth Planet. Sci. Lett., 45:383-393.

Berger, W. H., Killingley, J. S., and Vincent, E., 1978. Stable isotopes in deep-sea carbonates: Box core ERDC-92, West equatorial Pacific. Oceanol. Acta, 1:203-216.

Boersma, A., and Shackleton, N. J., 1981. Oxygen- and carbon-isotope variations and planktonic-foraminifer depth habitats, Late Cretaceous to Paleocene, Central Pacific, Deep Sea Drilling Project Sites 463 and 465. In Thiede, J., Vallier, T. L., et al., Init. Repts. DSDP, 62: Washington (U.S. Govt. Printing Office), 513-526.
Boersma, A., Shackleton, N. J., Hall, M. A., and Given, Q. C., 1979. Carbon and oxygen isotope records at DSDP Site 384 (North Atlantic) and some Paleocene paleotemperatures and carbon isotope variations in the Atlantic Ocean. In Tucholke, B. E., Vogt, P. R., et al., Init. Repts. DSDP, 43: Washington (U.S. Govt. Printing Office), 695-717.

Broecker, W. S., 1974. Chemical Oceanography: New York (Harcourt, Brace, Jovanovich).

Douglas, R. G., and Savin, S. M., 1971. Isotopic analysis of planktonic foraminifera from the Cenozoic of the Northwest Pacific, Leg 6. In Fischer, A. G., Heezen, B. C., et al., Init. Repts. DSDP, 6: Washington (U.S. Govt. Printing Office), 1123-1127.

Haq, B. U., Worsley, J. R., Burckle, L. H., Douglas, R. G., Keigwin, L. D., Jr., et al., 1980. Late Miocene marine carbon isotopic shift and synchroneity of some phytoplanktonic biostratigraphic events. Geology, 8:427-431.

Hsü, K. J., He, Q., McKenzie, J. A., Weissert, H., Perch-Nielsen, K., Oberhänsli, H., et al., 1982. Mass mortality and its environmental and evolutionary consequences. Science, 216:249-255.

Keigwin, L. D., Jr., 1979. Late Cenozoic stable isotope stratigraphy and paleoceanography of DSDP sites from the east equatorial and central North Pacific Ocean. Earth Planet. Sci. Lett., 45:361-382.

Keigwin, L. D., Jr., and Shackleton, N. J., 1980. Uppermost Miocene carbon isotope stratigraphy of a piston core in the equatorial $\mathrm{Pa}$ cific. Nature, 284:613-614.

Létolle, R., and Renard, M., 1980. Sedimentologie-Evolution des teneurs en ${ }^{13} \mathrm{C}$ des carbonates pelagiques aux limites Cretace-Tertiare et Paleocene-Eocene. C. R. Acad. Sci. Paris, 290:827-830.

Premoli Silva, I., 1977. Upper Cretaceous-Paleocene magnetic stratigraphy at Gubbio, Italy: II. Biostratigraphy. Geol. Soc. Am. Bull., 88:371-374.

Renard, M., Delacotte, O., and Létolle, R., in press. Etude geochimique comparée (teneur en strontium et isotopes stables sur carbonates totaux) de quelques sites de l'Atlantique nord, de l'Atlantique sud, et de la Tethys. Bull. Soc. géol. France.

Shackleton, N. J., 1977. Carbon-13 in Uvigerina: Tropical rainforest history and the Equatorial Pacific carbonate dissolution cycles. In Andersen, N. R., and Malahoff, A. (Eds.), The Fate of Fossil Fuel $\mathrm{CO}_{2}$ in the Oceans: New York (Plenum), 401-427.

Shackleton, N. J., and Kennett, J. P., 1975. Paleotemperature history of the Cenozoic and the initiation of Antarctic glaciation: Oxygen and carbon isotope analyses in DSDP Sites 277, 279, and 281. In Kennett, J. P., Houtz, R. E., et al., Init. Repts. DSDP, 29: Washington (U.S. Govt. Printing Office), 743-775.

Shackleton, N. J., and Opdyke, N. D., 1973. Oxygen isotope and palaeomagnetic stratigraphy of Equatorial Pacific core V28-238: Oxygen isotope temperatures and ice volumes on a $10^{5}$ year and $10^{6}$ year scale. Quat. Res., 3:39-55.

Scholle, P. A., and Arthur, M. A., 1980. Carbon isotope fluctuations in Cretaceous pelagic limestones: Potential stratigraphic and petroleum exploration tool. Am. Assoc. Pet. Geol. Bull., 64:67-87.

Thierstein, H. R., 1981. Late Cretaceous nannoplankton and the change at the Cretaceous/Tertiary boundary. In Warme, T. E., Douglas, R. C., and Winterer, E. L. (Eds.), The Deep Sea Drilling Project: A Decade of Progress. Soc. Econ. Paleont. Mineral., Spec. Publ., 32:355-394.

Thierstein, H. R., and Berger, W. H., 1978. Injection events in ocean history. Nature, 276:461-466.

Vincent, E., Killingley, J. S., and Berger, W. H., 1980. The magnetic Epoch-6 carbon shift: A change in the ocean's ${ }^{13} \mathrm{C} /{ }^{12} \mathrm{C}$ ratio 6.2 million years ago. Mar. Micropaleontol., 5:185-203. 
APPENDIX

Oxygen and Carbon Data by Depth

\begin{tabular}{|c|}
\hline $\begin{array}{l}\text { Sub-bottom } \\
\text { Depth } \\
\text { (m) }\end{array}$ \\
\hline Hole 525 \\
\hline 0.10 \\
\hline 1.70 \\
\hline 3.10 \\
\hline 3.81 \\
\hline 4.47 \\
\hline 4.47 \\
\hline 5.11 \\
\hline 6.61 \\
\hline 7.97 \\
\hline 11.95 \\
\hline 16.84 \\
\hline 19.73 \\
\hline 24.66 \\
\hline 29.54 \\
\hline 38.61 \\
\hline 47.13 \\
\hline 48.25 \\
\hline 89.56 \\
\hline 73.74 \\
\hline 75.84 \\
\hline 82.49 \\
\hline 88.00 \\
\hline 95.04 \\
\hline 99.37 \\
\hline 103.54 \\
\hline 106.47 \\
\hline 112.57 \\
\hline 116.95 \\
\hline 117.25 \\
\hline 124.72 \\
\hline 130.25 \\
\hline 135.05 \\
\hline 138.45 \\
\hline 146.72 \\
\hline 150.33 \\
\hline 156.33 \\
\hline 160.57 \\
\hline 164.90 \\
\hline 170.00 \\
\hline Hole 525A \\
\hline \\
\hline 184.35 \\
\hline 192.68 \\
\hline 211.92 \\
\hline 219.70 \\
\hline 231.91 \\
\hline 241.40 \\
\hline 260.37 \\
\hline 263.91 \\
\hline 269.60 \\
\hline 270.80 \\
\hline 272.30 \\
\hline 273.80 \\
\hline 275.30 \\
\hline 276.50 \\
\hline 278.30 \\
\hline 279.10 \\
\hline 279.63 \\
\hline 281.10 \\
\hline 282.60 \\
\hline 284.10 \\
\hline 287.10 \\
\hline 287.33 \\
\hline 289.01 \\
\hline 290.51 \\
\hline 292.01 \\
\hline 293.50 \\
\hline 295.01 \\
\hline 298.00 \\
\hline 298.22 \\
\hline 301.19 . \\
\hline 301.29 \\
\hline 301.39 \\
\hline 301.49 \\
\hline 301.59 \\
\hline 301.69 \\
\hline 301.79 \\
\hline 301.89 \\
\hline 301.99 \\
\hline 302.09 \\
\hline 302.19 \\
\hline 302.29 \\
\hline 302.39 \\
\hline 303.30 \\
\hline 307.06 \\
\hline 321.69 \\
\hline 321.79 \\
\hline 321.89 \\
\hline 321.99 \\
\hline 322.07 \\
\hline 322.19 \\
\hline 322.29 \\
\hline 322.37 \\
\hline 322.53 \\
\hline 322.59 \\
\hline 322.69 \\
\hline
\end{tabular}


CARBON ISOTOPE DATA, LEG 74

Appendix. (Continued).

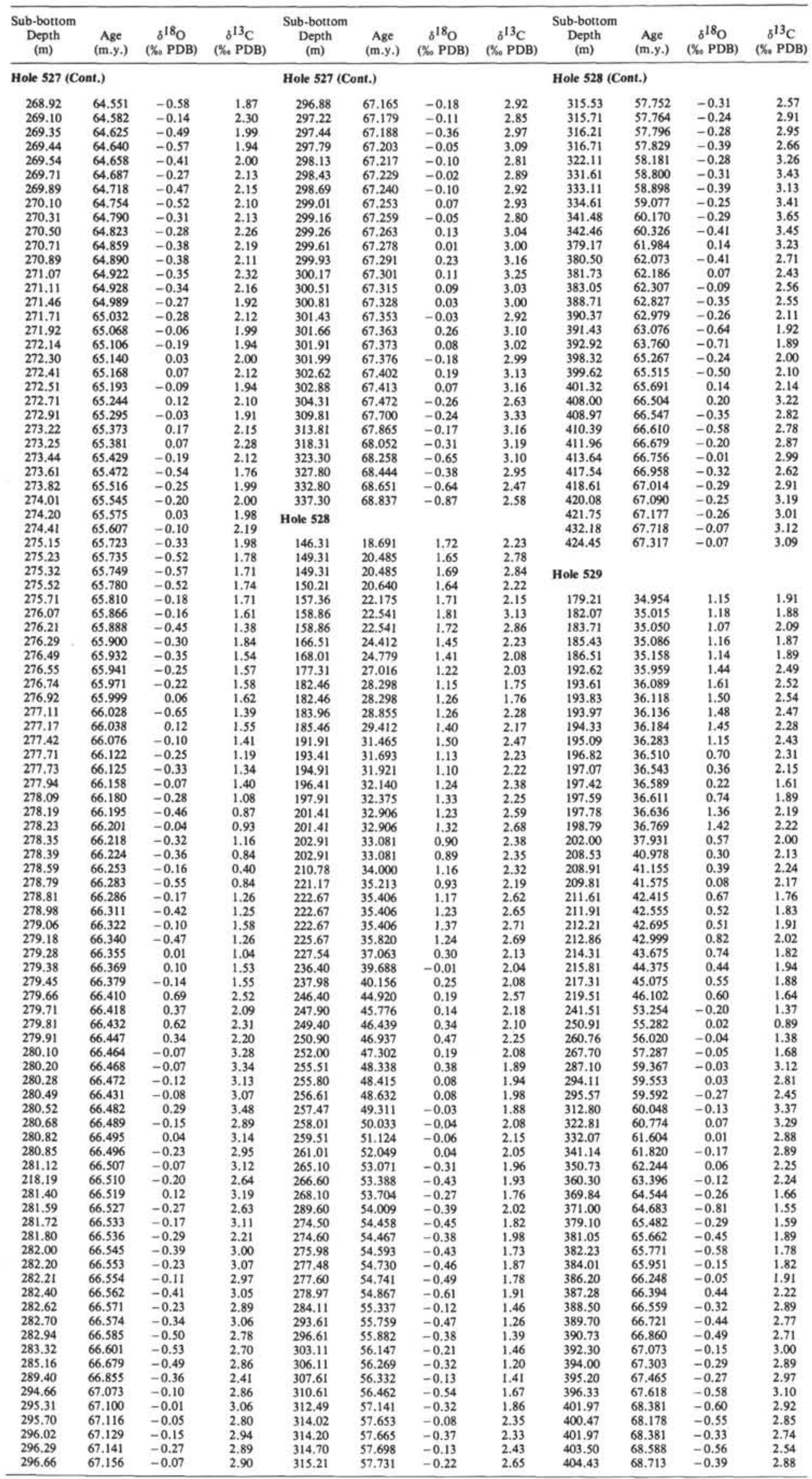

Note: Ages are estimated as described in Shackleton et al, (this volume). All samples are bulk sediment. 